\title{
Light-response characteristics of photosynthesis of drip-irrigated sugar beet under different nitrogen fertilizer managements
}

\author{
C. FEI, J.X. SU, Y.Y. LI, Z.F. LI, K.Y. WANG, H. FAN ${ }^{+}$, and F.Y. MA ${ }^{+}$ \\ Agricultural College, Shihezi University, 832003 Shihezi, China
}

\begin{abstract}
Effects of two split application ratios of nitrogen fertilizer (R1: half of the total nitrogen fertilizer was applied on 13 June, and the rest was applied on 1 July; R2: two equal amounts of $\mathrm{N}$ fertilizer accounting for $70 \%$ of total were applied on 15 June and 1 July, respectively, and the rest was applied on 1 August) and three $\mathrm{N}$ fertilizer application rates (75, 150 , and $225 \mathrm{~kg} \mathrm{ha}^{-1}$ ) on chlorophyll content, photosynthetic characteristics, and root yield of sugar beets were studied. The results showed that with $\mathrm{N}$ fertilizer application rates of 150 and $225 \mathrm{~kg} \mathrm{ha}^{-1}$, R2 treatment significantly decreased light-compensation point, but increased light-saturation point and actual photochemical efficiency at the storage root development compared to R1 treatment. The R2 treatment with the $\mathrm{N}$ fertilizer application rate of $150 \mathrm{~kg} \mathrm{ha}^{-1}$ significantly increased sugar yield by $5-29 \%$ compared to other treatments.
\end{abstract}

Additional key words: Beta vulgaris; chlorophyll fluorescence; gas exchange; nitrogen content; sugar production.

\section{Introduction}

Sugar beet is the second crop in the use for sugar production worldwide (Jay et al. 2017). Sugar from sugar beets accounts for approximately $26 \%$ of total sugar production in China (Geng and Yang 2015). In recent years, due to the natural disasters and market volatility, Chinese sugar production has been in short supply. Xinjiang is one of primary sugar production bases in China, and its sugar beet yield ranks first in China (Fan et al. 2016). The sugar content of sugar beets planted in Xinjiang, however, has been declining. With the implementing of 'price in accordance with quality' by sugar-refining companies, in order to ensure the yield of tuberous roots, while also improving the quality, it is an urgent problem to be solved.

The $\alpha-\mathrm{N}$ (ammonia nitrogen) is one of the most important factors affecting the tuberous root quality of sugar beets; it contributes to the formation of a kind of honey-like nonsugar substance that reduces sugar content which cannot be removed by washing and filling processes during sugar refining. The main components of the substance include amino acids, betaine, and nitrate $\mathrm{N}$. The betaine content in tuberous roots is basically stable for the entire growth stage, while the contents of total $\mathrm{N}$ and various forms of $\mathrm{N}$ are greatly affected by cultivation and climate (Qu and Cui 1994). Previous studies have shown that when $\mathrm{N}$ supply is insufficient, $\mathrm{N}$ is always accumulated in the highly competitive new leaves, causing older leaves to wither early, which, thereby, affects the tuberous root expansion and sugar accumulation during the late growth stage and leads to a decrease in yield. Excess N, however, always leads to the vigorous growth of aboveground tissues and late ripening, increasing the contents of $\alpha-\mathrm{N}$ and ash in tuberous roots (Bagherzadeh et al. 2014, Kiymaz and Ertek 2015, Barzegari et al. 2017). In addition, due to the rapid decrease in $\mathrm{N}$ uptake during the middle and late growth stages of sugar beets, the $\mathrm{N}$ demand for tuberous roots is mainly met by the reuse of the $\mathrm{N}$ accumulated in sugar beet leaves during the early and middle growth stages (Shao 1991). The N should be applied to soil before the middle growth stage; otherwise, it will reduce tuberous root quality (Malnou et al. 2008). However, some studies have suggested that a small amount of $\mathrm{N}$ applied during the late growth stage of sugar beet could delay leaf and root senescence and increase the yield and sugar content of tuberous roots (Tsialtas and Maslaris 2008). Therefore, how to use $\mathrm{N}$ to coordinate the root and leaf growth and to maintain adequate photosynthetic capacity without reducing tuberous root quality during late growth stage is important for the drip-irrigated sugar beet cultivation in arid areas.

Photosynthesis is the most important physiological

\footnotetext{
Received 21 June 2018, accepted 23 April 2019.

+Corresponding authors; e-mail: mfy-agr@shzu.edu.cn, fanhua@shzu.edu.cn

Abbreviations: AQE - apparent quantum efficiency; Chl - chlorophyll; $\mathrm{F}_{0}$ - minimal fluorescence yield of the dark-adapted state; $\mathrm{F}_{\mathrm{m}}$ - maximal fluorescence yield of the dark-adapted state; $\mathrm{F}_{\mathrm{m}}{ }^{\prime}-$ maximal fluorescence yield of the light-adapted state; $\mathrm{F}_{\mathrm{s}}-$ steady-state fluorescence yield; $\mathrm{F}_{\mathrm{v}}$ - variable fluorescence; $\mathrm{F}_{\mathrm{v}} / \mathrm{F}_{\mathrm{m}}$ - maximal quantum yield of PSII photochemistry; LCP - light-compensation point; LSP - light-saturation point; NCL - nitrogen content of leaves; $P_{\mathrm{N}}$ - photosynthetic rate; $P_{\mathrm{Nmax}}$ - light-saturated net photosynthetic rate; $R_{\mathrm{D}}$ - dark respiration; $\Phi_{\mathrm{PSII}}-$ effective quantum yield of PSII photochemistry.

Acknowledgements: This work was supported by the National Natural Science Foundation of China (31771720, 31660360); PhD Fund Project (2014BB012); Xinjiang Production and Construction Corps; Research and Innovation Project of graduate students in Autonomous Region (XJGRI2016039); International Science and Technology Cooperation Promotion Program of Shihezi University (GJHZ201706).
} 
activity in green plants; it provides necessary materials and energy for growth and determines the yield and quality (Zheng et al. 2013). Crops have different lightresponse characteristics at different growth stages. Studying the light-response characteristics increases the understanding of photosynthesis (Lang et al. 2011, Duan et al. 2017). Chl fluorescence allows the rapid detection of plant photosynthesis and is commonly used to evaluate the functions of photosynthetic organs (Lin et al. 2013). Studies on the relation between plant photosynthesis and $\mathrm{N}$ have shown that the application of $\mathrm{N}$ can increase Chl content and improve the activities of related enzymes to increase the photosynthetic capacity of leaves. When $\mathrm{N}$ application rate is decreased, photosynthetic capacity is reduced (Westoby 2004, Pal et al. 2005, Li et al. 2013). Nitrogen has a significant effect on Chl fluorescence parameters (Khamis et al. 1990, Hák et al. 1993, Shangguan et al. 2000, Li et al. 2015), affecting leaf photosynthesis and root yield and quality of sugar beets (Bindraban 1999, Ruiz et al. 2008, Miranzadeh et al. 2011). Nitrogen affects plant photosynthetic efficiency by affecting the maximum net photosynthetic rate, light-compensation point, lightsaturation point, and dark respiration rate in response to light; such effect has also been demonstrated in crops such as corn, wheat, and rice (Sun et al. 2009, Wang et al. 2014, Zhang et al. 2015, 2017b). However, few studies have focused on light-response characteristics and Chl fluorescence parameters of sugar beets with different split application ratios of $\mathrm{N}$ fertilizer. Therefore, we hypothesized that nitrogen fertilizer application rate and split application ratio might affect photosynthetic characteristics of sugar beet leaves, thereby affecting yield and quality of tuberous roots. In this study, the experiment with different nitrogen fertilizer application rates and split application ratios was designed, and the light-response characteristics of leaf photosynthesis of sugar beets with different split application ratios were determined to provide references for scientific $\mathrm{N}$ fertilizer application in drip-irrigated sugar beet cultivation in arid areas.

\section{Materials and methods}

Study area: This study was conducted at the experimental station of Agricultural College, Shihezi University, China $\left(44^{\circ} 20^{\prime} \mathrm{N}, 88^{\circ} 30^{\prime} \mathrm{E}\right)$ from April to October 2016 . The study area belongs to the temperate continental climate. The average temperature during the entire growth stage was $21.2^{\circ} \mathrm{C}$, the average annual rainfall was $189.1-200.3 \mathrm{~mm}$, the annual evaporation was 1,517.5-1,563.8 $\mathrm{mm}$, and the average frost-free stage was $170 \mathrm{~d}$. The $0-20 \mathrm{~cm}$ tillage layer is irrigated gray desert soil, and the texture is heavy loam. The soil tilled layer has $0.76 \mathrm{~g}$ (total N) $\mathrm{kg}^{-1}, 0.021 \mathrm{~g}$ (available P) $\mathrm{kg}^{-1}, 0141 \mathrm{~g}$ (available K) $\mathrm{kg}^{-1}, 0.063 \mathrm{~g}$ (alkalihydrolysable N) $\mathrm{kg}^{-1}$, and $13.27 \mathrm{~g}$ (organic matter) $\mathrm{kg}^{-1}$. Soil $\mathrm{pH}$ is 7.5 .

Experimental design: In this experiment, two split application ratios [R1: half of the nitrogen fertilizer [CO $\left.\left(\mathrm{NH}_{2}\right)_{2}\right]$ $(46 \% \mathrm{~N})$ was applied with drip irrigation on 13 June, and the rest was applied on 1 July (at the canopy development);
R2 (nitrogen fertilizer postponed): two equal amounts of $\mathrm{N}$ fertilizer accounting for $70 \%$ totally were applied with drip irrigation on 15 June and 1 July, respectively (at the canopy development), and the rest was applied on 1 August (at the storage root development)] and three application rates $\left(\mathrm{N} 1: 75 \mathrm{~kg} \mathrm{ha}^{-1}, \mathrm{~N} 2: 150 \mathrm{~kg} \mathrm{ha}^{-1}\right.$, and N3: $225 \mathrm{~kg} \mathrm{ha}^{-1}$ ) were included in the test with a completely randomized design. A $1-\mathrm{m}$ wide border between each plot $(4 \times 6 \mathrm{~m})$ was set, and three replicates were included for each treatment. Irrigation $\left(7,500 \mathrm{~m}^{3} \mathrm{ha}^{-1}\right)$ was applied during the entire growth stage, with one drip irrigation tape laid between two rows of sugar beets. $\mathrm{P}$ and $\mathrm{K}$ fertilizers $\left[345 \mathrm{~kg}\left(\mathrm{P}_{2} \mathrm{O}_{5}\right) \mathrm{ha}^{-1}\right.$; $\left.210 \mathrm{~kg}\left(\mathrm{~K}_{2} \mathrm{O}\right) \mathrm{ha}^{-1}\right]$ were applied once as base fertilizers. Sugar beet seeds (Beta356, Beta Seed Company, USA) were sown on 20 April, with a row spacing of $20 \mathrm{~cm}$ and a plant spacing of $50 \mathrm{~cm}$.

$\boldsymbol{P}_{\mathrm{N}}$-PAR curve fitting method: After all $\mathrm{N}$ fertilizer was applied, sunny and cloudless days were selected at the end of storage root development (23 August) and sugar accumulation stage (17 September) to measure the lightresponse characteristics for functional leaves (the $15^{\text {th }}$ leaf at the storage root development and the $35^{\text {th }}$ leaf at the sugar accumulation stage) with the $L i-6400 X T$ (LI-COR, USA) portable photosynthesis system. The red and blue light sources were used to set 2,$400 ; 2,200 ; 1,800 ; 1,600 ; 1,200$; $800,600,400,200,150,100,50$, and $0 \mu \mathrm{mol}$ (photon) $\mathrm{m}^{-2} \mathrm{~s}^{-1}$; data were obtained after stabilization.

The nonrectangular hyperbola model proposed by Thornley (1976) was used to describe the light response characteristics:

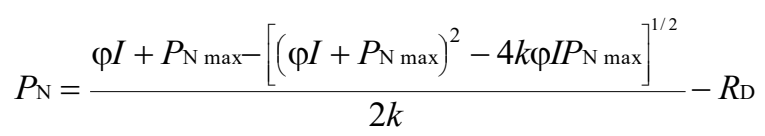

where $P_{\mathrm{N}}$ is the net photosynthetic rate $\left[\mu \mathrm{mol} \mathrm{m} \mathrm{m}^{-2} \mathrm{~s}^{-1}\right.$; $\varphi$ is the AQE $\left[\mathrm{mol} \mu \mathrm{mol}^{-1}\right] ; P_{\mathrm{Nmax}}$ is the light-saturated net photosynthetic rate $\left[\mu \mathrm{mol} \mathrm{m} \mathrm{m}^{-2} \mathrm{~s}^{-1}\right] ; I$ is the photosynthetic active radiation $\left[\mu \mathrm{mol} \mathrm{m} \mathrm{m}^{-2} \mathrm{~s}^{-1}\right.$; $k$ is the photoresponse curve angle (dimensionless); and $R_{\mathrm{D}}$ is the dark respiration rate $\left[\mu \mathrm{mol} \mathrm{m} \mathrm{m}^{-2} \mathrm{~s}^{-1}\right.$. Data fitting was performed to obtain the maximum net photosynthetic rate $\left(P_{\mathrm{Nmax}}\right)$, apparent quantum efficiency (AQE), light-compensation point (LCP), light-saturation point (LSP), dark respiration rate $\left(R_{\mathrm{D}}\right)$, and curve angle $(k)$. Linear regression was performed for $0-200 \mu \mathrm{mol}\left(\right.$ photon) $\mathrm{m}^{-2} \mathrm{~s}^{-1}$. The intersections of regression lines with the two horizontal lines and the net photosynthetic rates at 0 ( $x$-axis) and $P_{\mathrm{N} \max }$ are the LCPs and LSPs, respectively (Ye and Yu 2008).

Acquisition of PSII Chl fluorescence parameters: Sugar beet leaves after the measurement of light-response characteristics were used to measure the initial fluorescence yield $\left(\mathrm{F}_{0}\right)$ and the maximum fluorescence yield $\left(\mathrm{F}_{\mathrm{m}}\right)$ under dark adaptation with PAM-2500 chlorophyll fluorometer (Walz, Germany). After the fluorescence value stabilized, the saturation pulse light was turned on to determine the steady-state fluorescence yield $\left(\mathrm{F}_{\mathrm{s}}\right)$ at any time and the maximum fluorescence yield $\left(\mathrm{F}_{\mathrm{m}}{ }^{\prime}\right)$ under light adaptation. The $\mathrm{F}_{\mathrm{v}} / \mathrm{F}_{\mathrm{m}}$ was calculated as $\left(\mathrm{F}_{\mathrm{m}}-\mathrm{F}_{0}\right) / \mathrm{F}_{\mathrm{m}}$. The $\Phi_{\text {PSII }}$ was 
calculated as $\left(\mathrm{F}_{\mathrm{m}}{ }^{\prime}-\mathrm{F}_{\mathrm{s}}\right) / \mathrm{F}_{\mathrm{m}}{ }^{\prime}$.

Determination of the leaf pigment content: Sugar beet leaves after the measurement of $\mathrm{Chl}$ fluorescence parameters were used. Destructive sampling was carried out, and the photosynthetic pigment content was determined with the method of Arnon (Jagtap et al. 2011). Total Chl was determined with spectrophotometer I3 (Hai Neng, China).

Statistical analysis: The data were statistically analyzed using analysis of variance (ANOVA) and Duncan's multiple range tests at $P<0.05$ or $P<0.01$ with the SPSS 12.0 software (SPSS Inc., Chicago, USA). Plotting was completed with software Origin 8.5 (OriginLab, USA).

\section{Results}

Light-response curves: The $P_{\mathrm{N}}$ gradually decreased with the growth of sugar beets. With the application rate of N1, R2 treatment could not significantly increase the $P_{\mathrm{N}}$ during the late growth stage compared to $\mathrm{R} 1$ treatment (Fig. $1 C, D$ ). However, with the application rates of N2 and N3, R2 treatment significantly increased the $P_{\mathrm{N}}$ at the storage root development (Fig. 1 $A, B$ ) but had no significant effect at the sugar accumulation stage compared with $\mathrm{R} 1$ treatment (Fig. 1C,D).

Light-response curve fitting parameters: The results showed that the nonrectangular hyperbolic model could describe the parameters of light-response characteristics well, and all coefficients of determination for the fitting curves were above 0.95 (Table 1). For R1 and R2 treatments, the $P_{\mathrm{Nmax}}$ and AQE at storage root development with the application rate of N3 were higher than those with the application rates of $\mathrm{N} 1$ and $\mathrm{N} 2$; with the application rates of N2 and N3, R1 treatment significantly increased the $P_{\text {Nmax }}$ by 25.1 and $36.7 \%$, respectively, and R2 treatment significantly increased the $P_{\mathrm{Nmax}}$ by 106.6 and $127.0 \%$, respectively, compared to those with the application rate of N1. The LSP increased first and then decreased with the increase of nitrogen fertilizer application rate, but the changes of $R_{\mathrm{D}}$ and LCP had no obvious regularity. For R1 and R2 treatments, the $P_{\mathrm{N} \max }$ at sugar accumulation stage with the application rate of $\mathrm{N} 2$ were higher than those with $\mathrm{N} 1$ and N3, and the LCP with the application rate of N1 were higher than those with N2 and N3. The changes of $\mathrm{AQE}, \mathrm{LSP}$, and $R_{\mathrm{D}}$ had no obvious regularity (Table 1 ).

At storage root development, with the application rate of N1, the $P_{\mathrm{Nmax}}$ and LSP for R1 treatment were 49.8 and $4.2 \%$ higher than those for $\mathrm{R} 2$ treatment, respectively; with the application rates of $\mathrm{N} 2$ and N3, the $P_{\mathrm{Nmax}}$ for R2 treatment were 10.2 and $11.1 \%$ higher than those for R1 treatment, respectively, and the LSP for R2 treatment were 22.0 and $10.5 \%$ higher than those for $\mathrm{R} 1$ treatment, respectively. The AQE for R1 and R2 treatments had no significant difference, while the LCP and $R_{\mathrm{D}}$ for R1 treatment were significantly higher than those for R2 treatments. At sugar accumulation stage, the $P_{\mathrm{Nmax}}$ and AQE for R1 and R2 treatments had no significant difference; the LCP and LSP for R1 treatments were significantly higher than those for R2 treatments; and the change of $R_{\mathrm{D}}$ had no obvious regularity (Table 1).

Relationships between photosynthetic capacity and biological factors: The nitrogen content of leaf increased with theincreaseofnitrogenfertilizerapplicationrate(Fig.2). At the storage root development, with the application rates of $\mathrm{N} 1$ and $\mathrm{N} 2$, the nitrogen contents of leaf for R2 treatments were 21.1 and $12.3 \%$ higher than those for R1 treatments, respectively; and there was no significant difference in nitrogen content of leaf between R1 and R2 treatments with the application rate of $\mathrm{N} 3$ (Fig. 2A,B). At the sugar accumulation stage, there was no significant difference in the nitrogen content of leaf between $\mathrm{R} 1$ and $\mathrm{R} 2$ treatments with the three application rates (Fig. $2 C, D$ ).

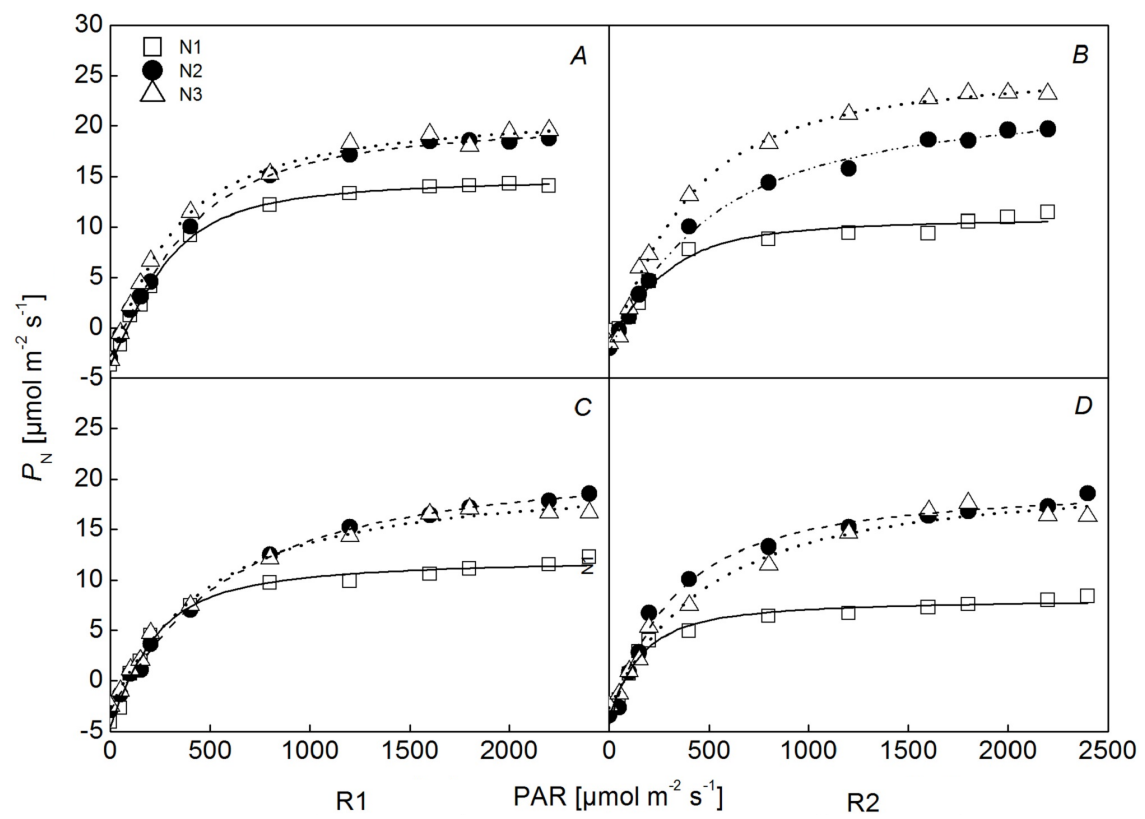

Fig. 1. Light-response curves of sugar beet plants under different $\mathrm{N}$ fertilizer management. Light-response curves under split application ratio $\mathrm{R} 1(A)$ and $\mathrm{R} 2(B)$ in storage root development. Light-response curves under split application ratio R1 $(C)$ and R2 $(D)$ in sugar accumulation stage. Values are means of three replicates. $\mathrm{N} 1, \mathrm{~N} 2$, and N3 indicate 75,150 , and $225 \mathrm{~kg}(\mathrm{~N}$ fertilizer $) \mathrm{ha}^{-1}$, respectively. PAR - photosynthetically active radiation, $P_{\mathrm{N}}-$ photosynthetic rate. 
The $P_{\text {Nmax }}$ and LSP at storage root development and sugar accumulation stage and the AQE at storage root development had a positive relation with the leaf nitrogen content. However, the LCP at storage root development and sugar accumulation stage and the AQE at sugar accumulation stage had a negative relation with nitrogen content of leaf (Table 3 ).

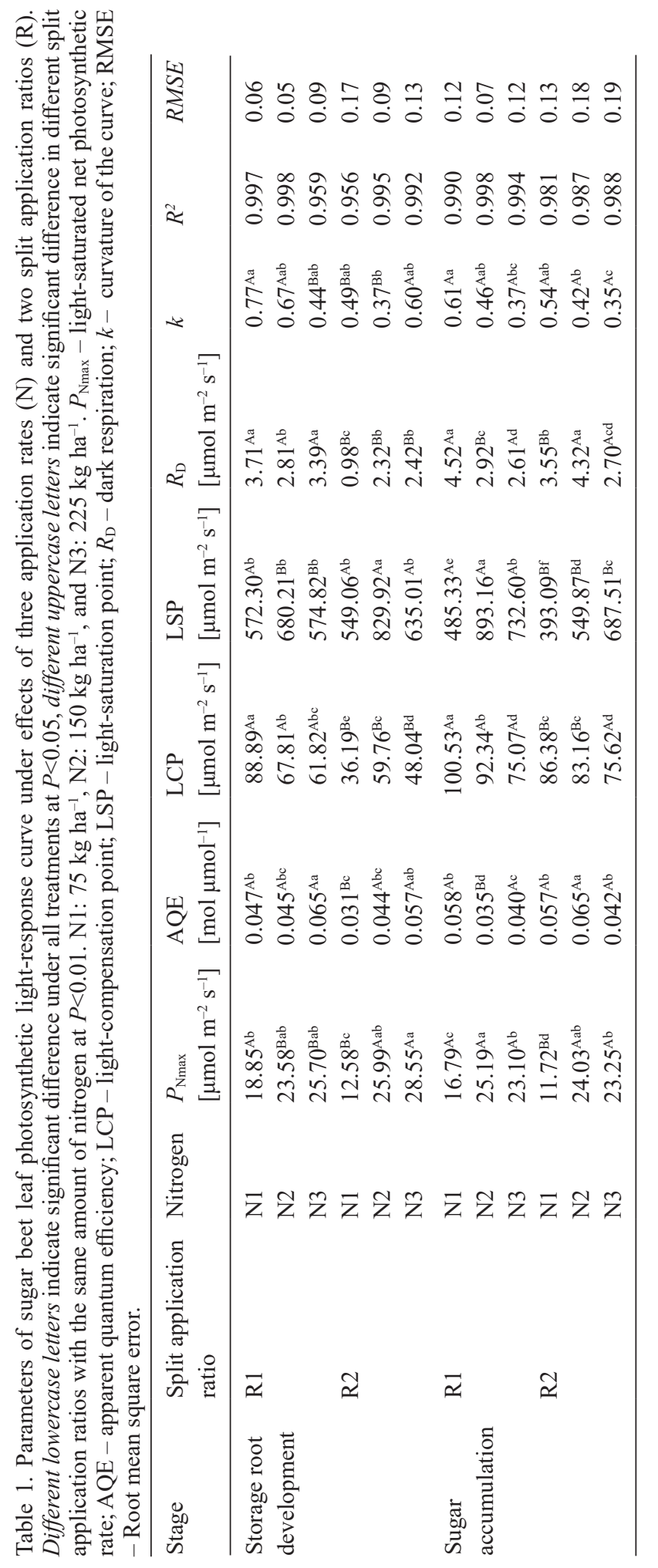

Leaf Chl content and $\mathrm{Chl}$ fluorescence parameters: With the growth of sugar beets, the Chl content of leaf decreased slightly. The $\mathrm{N}$ fertilizer split application ratios, application rates, and their coeffect had significant effects on the Chl content. The Chl content for R2 treatment with the application rate of $\mathrm{N} 2$ was the highest during the late growth stage, and it was significantly higher than those for other treatments (Fig. 3A,B).

The three application rates and two split application ratios had no significant effect on the maximum photochemical efficiency $\left(\mathrm{F}_{\mathrm{v}} / \mathrm{F}_{\mathrm{m}}\right)$ of PSII, which was above 0.8 for all treatments (Fig. 3C,D). The actual photochemical efficiency $\left(\Phi_{\mathrm{PSII}}\right)$ for $\mathrm{R} 1$ and $\mathrm{R} 2$ treatment with the application rate of N2 was higher than those with the application rates of $\mathrm{N} 1$ and $\mathrm{N} 3$ during the storage root development; and the $\Phi_{\text {PSII }}$ for R2 treatment was higher than that for R1 treatment with the same application rate. There was no significant difference in the $\Phi_{\text {PSII }}$ between all treatments during sugar accumulation stage (Fig. $3 E, F$ ).

Yield and quality: The effects of the three application rates and two split application ratios on yield and quality of tuberous roots were different (Table 4). The sugar yield and root quality were significantly affected by split application ratios, application rates, and their coeffect. The root yield and the contents of $\mathrm{Na}, \mathrm{K}$, and $\alpha-\mathrm{N}$ increased with the increase of nitrogen fertilizer application rate. The sugar content and sugar yield increased first and then decreased with the increase of nitrogen fertilizer application rate; sugar contents and sugar yields were the highest with the application rate of N2. With the same application rate, R1 and R2 treatments had different effects on the quality and yield of sugar beet tuberous roots (Table 4). With the application rate of N1, the root yield for R1 treatment was $4.4 \%$ higher than that for R2 treatment; with the application rate of N2, the root yield for R2 treatment was $5.3 \%$ higher than that for R1 treatment. There was

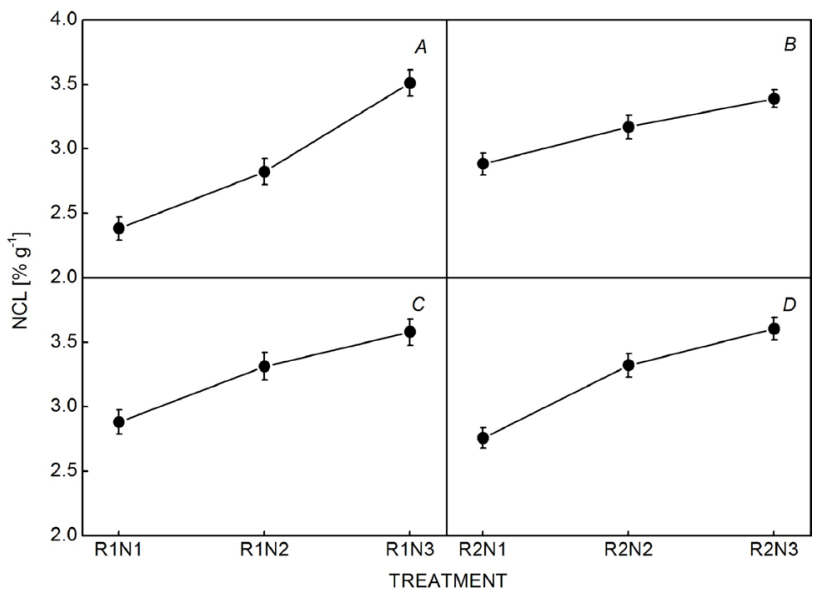

Fig. 2. Changes of nitrogen content in leaves (NCL) of sugar beet in storage root development stage under R1 $(A)$ and $\mathrm{R} 2(B)$ split application ratio and in sugar accumulation stage under $\mathrm{R} 1(C)$ and R2 (D) split application ratio. Values are means of three replicates \pm SD. N1, N2, and N3 indicate 75, 150, and $225 \mathrm{~kg}$ (N fertilizer) ha ${ }^{-1}$, respectively. 
Table 2. Significance analysis of nitrogen application rate $(\mathrm{N})$, split application ratios $(\mathrm{R})$, and their coeffect $(\mathrm{R} \times \mathrm{N})$ on light-response characteristics of sugar beet. * - influence is significant at the 0.05 level, ** - influence is highly significant at the 0.01 level, ns - not significant. $P_{\mathrm{N} \max }-$ light-saturated net photosynthetic rate; AQE - apparent quantum efficiency; LCP - light-compensation point; LSP - light-saturation point; $R_{\mathrm{D}}$ - dark respiration; $k$ - curvature of the curve.

\begin{tabular}{llllllll}
\hline Stage & Source of variation & $P_{\mathrm{Nmax}}$ & AQE & LCP & LSP & $R_{\mathrm{D}}$ & $k$ \\
\hline Storage root development & $\mathrm{R}$ & $\mathrm{ns}$ & $\mathrm{ns}$ & $* *$ & $\mathrm{~ns}$ & $* *$ & $\mathrm{~ns}$ \\
& $\mathrm{~N}$ & $* *$ & $* *$ & $* *$ & $\mathrm{~ns}$ & $* *$ & $\mathrm{~ns}$ \\
& $\mathrm{R} \times \mathrm{N}$ & $* *$ & $\mathrm{~ns}$ & $*$ & $* *$ & $\mathrm{~ns}$ & $\mathrm{~ns}$ \\
Sugar accumulation & $\mathrm{R}$ & $* *$ & $* *$ & $* *$ & $* *$ & $*$ & $\mathrm{~ns}$ \\
& $\mathrm{~N}$ & $* *$ & $* *$ & $* *$ & $* *$ & $* *$ & $* *$ \\
& $\mathrm{R} \times \mathrm{N}$ & $* *$ & $* *$ & $* *$ & $* *$ & $* *$ & $\mathrm{~ns}$ \\
\hline
\end{tabular}

Table 3. Correlation between nitrogen content of leaf and photosynthetic parameters at different stages of sugar beet plants. * - correlation is significant at the 0.05 level, $P_{\mathrm{N} \max }$ - light-saturated net photosynthetic rate; AQE - apparent quantum efficiency; LCP - light-compensation point; LSP - light-saturation point; $R_{\mathrm{D}}$ - dark respiration.

\begin{tabular}{|c|c|c|c|c|c|c|}
\hline Stage & & $P_{\text {Nmax }}$ & $\mathrm{AQE}$ & $\mathrm{LCP}$ & LSP & $R_{\mathrm{D}}$ \\
\hline Storage root development & $\mathrm{N}$ content & 0.640 & 0.601 & -0.544 & 0.194 & -0.124 \\
\hline Sugar accumulation & & $0.868^{*}$ & -0.585 & -0.728 & 0.730 & -0.653 \\
\hline
\end{tabular}

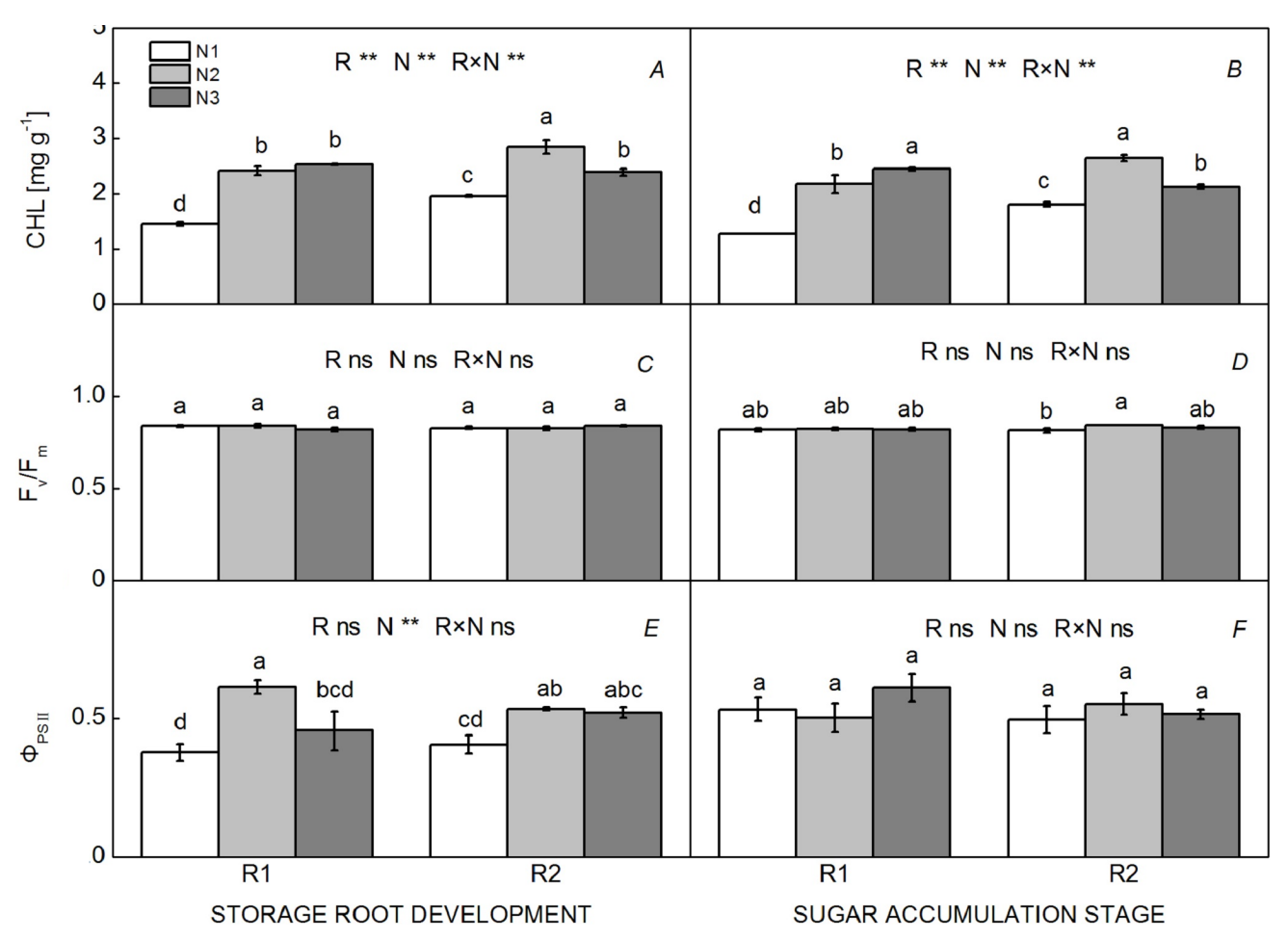

Fig. 3. Chlorophyll (Chl) content in storage root development $(A)$ and sugar accumulation stage $(B)$, maximal quantum yield of PSII photochemistry $\left(\mathrm{F}_{\mathrm{v}} / \mathrm{F}_{\mathrm{m}}\right)$ in storage root development $(C)$ and sugar accumulation stage $(D)$, effective quantum yield of PSII photochemistry $\left(\Phi_{\mathrm{PSII}}\right)$ in storage root development $(E)$, and sugar accumulation stage $(F)$ of sugar beet. Values are means of five replicates $\pm \mathrm{SD}$. Means of each parameter were analyzed using Duncan's multiple range tests to check the significance of difference between treatments. Columns marked with different lowercase letters indicate significant difference between treatments at $P<0.05$. N1, N2, and N3 indicate 75,150 , and $225 \mathrm{~kg}(\mathrm{~N}$ fertilizer $)$ ha $^{-1}$, respectively. ns - not significant, $* *$ - influence is highly significant at the 0.01 level..

no significant difference in root yield between R1 and R2 treatments with the application rate of N3. With the three application rates, there was no significant difference in sugar content between R1 and R2 treatments. The changes of sugar yield and root yield were similar. R2 treatment with the application rate of N2 significantly increased 
Table 4. Effects of three application rates $(\mathrm{N})$ and two split application ratios (R) on yield and quality of sugar beet. Different lowercase letters indicate significant difference under all treatments at $P<0.05$, different uppercase letters indicate significant difference in different split application ratios with the same amount of nitrogen at $P<0.01$. N1, N2, and N3 indicate 75, 150, and $225 \mathrm{~kg}\left(\mathrm{~N}\right.$ fertilizer) ha ${ }^{-1}$, respectively. ns - not significant, ${ }^{* *}$ - influence is highly significant at the 0.01 level.

\begin{tabular}{|c|c|c|c|c|c|c|c|}
\hline Split application ratio & Nitrogen & $\begin{array}{l}\text { Root yield } \\
{\left[\times 10^{3} \mathrm{~kg} \mathrm{hm}^{-2}\right]}\end{array}$ & $\begin{array}{l}\text { Sugar content } \\
{[\%]}\end{array}$ & $\begin{array}{l}\text { Sugar yield } \\
{\left[\times 10^{3} \mathrm{~kg} \mathrm{hm}^{-2}\right]}\end{array}$ & $\begin{array}{l}\mathrm{Na}^{+} \\
{\left[\mathrm{mmol} 100 \mathrm{~g}^{-1}\right]}\end{array}$ & $\begin{array}{l}\mathrm{K}^{+} \\
{\left[\mathrm{mmol} 100 \mathrm{~g}^{-1}\right]}\end{array}$ & $\begin{array}{l}\alpha-\mathrm{N} \\
{\left[\mathrm{mmol} 100 \mathrm{~g}^{-1}\right]}\end{array}$ \\
\hline \multirow[t]{3}{*}{$\mathrm{R} 1$} & N1 & $98.91^{\mathrm{Ac}}$ & $14.74^{\mathrm{Ab}}$ & $14.58^{\mathrm{Ac}}$ & $1.81^{\mathrm{Bd}}$ & $4.71^{\mathrm{Ac}}$ & $1.65^{\mathrm{Ae}}$ \\
\hline & $\mathrm{N} 2$ & $97.01^{\mathrm{Bc}}$ & $16.21^{\mathrm{Aa}}$ & $15.37^{\mathrm{Bb}}$ & $2.51^{\mathrm{Bc}}$ & $5.64^{\mathrm{Aa}}$ & $5.83^{\mathrm{Ab}}$ \\
\hline & $\mathrm{N} 3$ & $106.92^{\mathrm{Aa}}$ & $13.74^{\mathrm{Ab}}$ & $14.69^{\mathrm{Ac}}$ & $3.92^{\text {Аа }}$ & $5.03^{\mathrm{Ab}}$ & $6.08^{\mathrm{Aa}}$ \\
\hline \multirow[t]{3}{*}{$\mathrm{R} 2$} & N1 & $94.72^{\mathrm{Bd}}$ & $12.89^{\mathrm{Bc}}$ & $12.51^{\mathrm{Bd}}$ & $2.32^{\mathrm{Ac}}$ & $4.58^{\mathrm{Bc}}$ & $1.69^{\mathrm{Ae}}$ \\
\hline & $\mathrm{N} 2$ & $102.18^{\mathrm{Ab}}$ & $15.78^{\mathrm{Aab}}$ & $16.12^{\mathrm{Aa}}$ & $3.36^{\mathrm{Ab}}$ & $3.94^{\mathrm{Bd}}$ & $3.46^{\mathrm{Bd}}$ \\
\hline & N3 & $106.59^{\mathrm{Aa}}$ & $13.71^{\mathrm{Ab}}$ & $14.61^{\mathrm{Ac}}$ & $4.10^{\mathrm{Aa}}$ & $4.44^{\mathrm{Ac}}$ & $4.75^{\mathrm{Bc}}$ \\
\hline \multicolumn{8}{|l|}{ Source of variation } \\
\hline $\mathrm{R}$ & & ns & ns & $* *$ & $* *$ & $* *$ & $* *$ \\
\hline $\mathrm{N}$ & & $* *$ & $* *$ & $* *$ & $* *$ & ns & $* *$ \\
\hline $\mathrm{R} \times \mathrm{N}$ & & $* *$ & ns & $* *$ & $* *$ & $* *$ & $* *$ \\
\hline
\end{tabular}

sugar yield by $5-29 \%$ compared with other treatments. With the three application rates, the contents of sodium and potassium ions and $\alpha-\mathrm{N}$ in tuberous roots for $\mathrm{R} 2$ treatments were generally lower than those for R1 treatments. The sugar content and sugar yield for R2 treatment with the application rate of N2 were significantly higher than those for R1 and R2 treatments with the application rate of $\mathrm{N} 1$ and N3.

\section{Discussion}

Nitrogen is one of the most important nutrients that play a significant role in photosynthesis. Many studies have shown that when the $\mathrm{N}$ supply is increased within a certain range, the leaf $P_{\mathrm{N}}$, stomatal conductance, water-use efficiency, carboxylation efficiency, AQE, and maximum electron transfer rate can be improved (Duan et al. 2017, Gai et al. 2017, Bote et al. 2018), whereas excess N supply cannot improve the leaf photosynthesis continually but it eventually leads to reductions in some photosynthesis parameters. Our result showed that the $P_{\mathrm{N} \max }$ increased with the increase of nitrogen fertilizer application rate and was positively correlated with nitrogen content of leaf (Fig. 1, Table 3), which was consistent with results of Wang et al. (2014) and Sun et al. (2018). It may be due to the high Chl content and nitrogen content of the leafs. The AQE indicates the ability of crops to use weak light (Duan et al. 2017). Our results showed that nitrogen content of the leaf was positively correlated with the AQE during storage root development, and the application of nitrogen fertilizer in this stage could improve the use of weak light (Fig. 2). In the sugar accumulation stage, nitrogen content of leaf was negatively correlated with the AQE, while the nitrogen fertilizer postponement (R2) could improve the ability of sugar beet leaves to use weak light with the application rate of $\mathrm{N} 2$, which might be due to increasing nitrogen content in the early stage increased the activity of Rubisco in leaves, thus improving photosynthetic efficiency, while excessive application of nitrogen fertilizer increased the leaf putrescine content, affecting the photosynthesis during the later growth stages of leaves (Sun et al. 2018). The changes of the LCP and $R_{\mathrm{D}}$ were the same. For the same application rate, the LCP and $R_{\mathrm{D}}$ for $\mathrm{R} 1$ treatment were higher than those for R2 treatment; the LCP and $R_{\mathrm{D}}$ for $\mathrm{R} 1$ treatment decreased with the increasing application rate, while those for $\mathrm{R} 2$ treatment increased first and then decreased with the increasing application rate, which might be due to the coeffects of nitrogen fertilizer application rate and split application ratio (Table 2).

Chl plays an important role in photosynthesis (Chen 2014). Chl content indicates leaf light energy absorption and utilization (Lin et al. 2009). Our results showed that the $\mathrm{Chl}$ content increased with the increase of nitrogen fertilizer application rate, and beyond a certain range, Chl content of leaf cannot be affected by application rate, which was similar to the results of previous studies (Chen and Cheng 2004, Lin et al. 2016). With the application rates of N1 and N2, nitrogen fertilizer postponement (R2) could increase the $\mathrm{Chl}$ content of leaf during storage root development and sugar accumulation stage; with the application rate of $\mathrm{N} 3$, the split application ratio did not change the Chl content of leaf in the late growth stage. When external factors change, changes in Chl fluorescence parameters can reflect the effect of external factors on plants (Guarini and Moritz 2009). The three application rates and two split application ratios did not affect the $F_{v} / F_{m}$, which indicated that $\mathrm{N}$ fertilizer had little effect on the $\mathrm{F}_{\mathrm{v}} / \mathrm{F}_{\mathrm{m}}$. Some parameters of Chl fluorescence were significantly affected by nutrients. When nitrogen fertilizer was overapplied, the $\Phi_{\text {PSII }}$ decreased (Feng et al. 2015), which was similar to our results (Fig. $3 E, F$ ). With the application rates of $\mathrm{N} 2$ and $\mathrm{N} 3$, nitrogen fertilizer postponement could increase the $\Phi_{\text {PSII }}$ at storage root development, increasing the photosynthetic capacity of leaves.

Photosynthesis is a key factor affecting crop yield (Teng et al. 2004). More attention should be paid to improving photosynthetic efficiency and respiration rate to break down potential obstacles affecting the yield (Long et al. 
2015). Nitrogen fertilizer affects crop yield through affecting photosynthesis (Makino 2011). The application of nitrogen fertilizer can increase tuberous root yield (Kiymaz and Ertek 2015). Previous studies have found that the $P_{\mathrm{N} \max }$ can reflect crop yield (Zhang et al. 2017a). In our study, the $P_{\mathrm{Nmax}}$ and root yields for R1 and R2 treatments with the application rates of N2 and N3 were higher than those with N1 (Table 4). Liu and Li (2016) found that nitrogen deficiency in the early growth stage of rice would lead to the decrease of $P_{\mathrm{N}}$ in flag leaves. In our study, with the application rate of N1, nitrogen fertilizer postponement decreased the photosynthetic capacity at root storage development and sugar accumulation stage, limiting dry matter production. This might be due to the decrease of photosynthesis-related enzymes activity caused by nitrogen deficiency in the early stage. Yang et al. (2015) showed that nitrogen fertilizer postponement could increase Chl content of winter wheat leaves after anthesis, slow down the decrease of photosynthetic rate of flag leaves, and increase dry matter content. In our study with the application rates of $\mathrm{N} 2$ and N3, nitrogen fertilizer postponement could prolong the photosynthesis time of leaves at storage root development and improve the ability of leaves to use weak light at sugar accumulation stage, thereby improving photosynthesis, which was particularly significant with the application rate of N2. Cheng et al. (2015) showed that nitrogen fertilizer postponement could improve the yield of summer maize and nitrogen-use efficiency. The root yield also showed the same result: with the application rate of N2, nitrogen fertilizer postponement increased root yield and sugar yield (Table 4). Sylvite ( $\mathrm{KCl}$ in natural mineral form) and sodium salt are honey making agents, which can retard sucrose crystallization and have great influence on sucrose extraction rate. The contents of potassium ion and $\alpha-\mathrm{N}$ in tuberous roots for $\mathrm{R} 2$ treatments were lesser than those for R1 treatments with the three nitrogen fertilizer application rates, which indicated that the quality of sugar beet tuberous roots could be improved by nitrogen fertilizer postponement.

In conclusion, nitrogen fertilizer postponement and appropriate nitrogen fertilizer application rate can improve leaf photosynthesis and delay leaf senescence for dripirrigated sugar beets during the late growth stage, which can improve sugar yield and quality of sugar beet tuberous roots. Therefore, when applying nitrogen fertilizer during sugar beet cultivation, not only the influence of nitrogen fertilizer application rate, but also the influence of split application ratio should be considered.

\section{References}

Bagherzadeh A., Kalat S.M.N., Hajian J.: Effects of residual wheat straw and nitrogen fertilizer on yield and quality of sugar beet in a semi-arid region. - Sugar Tech 16: 189-194, 2014.

Barzegari M., Sepaskhah A.R., Ahmadi S.H.: Irrigation and nitrogen managements affect nitrogen leaching and root yield of sugar beet. - Nutr. Cycl. Agroecosys. 108: 211-230, 2017.

Bindraban P.S.: Impact of canopy nitrogen profile in wheat on growth. - Field Crop. Res. 63: 63-77, 1999.

Bote A.D., Zana Z., Ocho F.L., Vos J.: Analysis of coffee (Coffea arabica L.) performance in relation to radiation level and rate of nitrogen supply. II. Uptake and distribution of nitrogen, leaf photosynthesis and first bean yields. - Eur. J. Agron. 92: 107-114, 2018.

Chen L.S., Cheng L.L.: Photosynthetic enzymes and carbohydrate metabolism of apple leaves in response to nitrogen limitation. J. Hortic. Sci. Biotech. 79: 923-929, 2004.

Chen M.: Chlorophyll modifications and their spectral extension in oxygenic photosynthesis. - Annu. Rev. Biochem. 83: 317-340, 2014.

Cheng Y., Zhao J., Liu Z.X et al.: Modified fertilization management of summer maize (Zea mays L.) in northern China improves grain yield and efficiency of nitrogen use. - J. Integr. Agr. 14: 1644-1657, 2015.

Duan M., Yang W., Mao X.: [Effects of water deficit on photosynthetic characteristics of spring wheat under plasticmulching and comparison of light response curve models.] Trans. Chin. Soc. Agr. Mach. 12: 1-12, 2017. [In Chinese]

Fan H., Li Y., Fei C. et al.: Energy-use efficiency and economic analysis of sugar beet production in China: A case study in Xinxiang province. - Sugar Tech 18: 309-316, 2016.

Feng W., He L., Zhang H.Y.: Assessment of plant nitrogen status using chlorophyll fluorescence parameters of the upper leaves in winter wheat. - Eur. J. Agron. 64: 78-87, 2015.

Gai Z., Zhang J., Li C.: Effects of starter nitrogen fertilizer on soybean root activity, leaf photosynthesis and grain yield. PLoS ONE 12: e0174841, 2017.

Geng G., Yang J.: Sugar beet production and industry in China. Sugar Tech. 17: 13-21, 2015.

Guarini J.M., Moritz C.: Modelling the dynamics of the electron transport rate measured by PAM fluorimetry during Rapid Light Curve experiments. - Photosynthetica 47: 206-214, 2009.

Hák R., Rinderle-Zimmer U., Lichtenthaler H.K., Nátr L.: Chlorophyll $a$ fluorescence signatures of nitrogen deficient barley leaves. - Photosynthetica 28: 151-159, 1993.

Jagtap S.S., Awhad R.B., Santosh B., Vidyasagar P.B.: Effects of clinorotation on growth and chlorophyll content of rice seeds. Microgravity Sci. Tec. 23: 41-48, 2011.

Jay S., Maupas F., Bendoula R., Gorretta N.: Retrieving LAI, chlorophyll and nitrogen contents in sugar beet crops from multi-angular optical remote sensing: Comparison of vegetation indices and PROSAIL inversion for field phenotyping. - Field Crop. Res. 210: 33-46, 2017.

Khamis S., Lamaze T., Lemoine Y., Foyer C.: Adaptation of the photosynthetic apparatus in maize leaves as a result of nitrogen limitation: relationships between electron transport and carbon assimilation. - Plant Physiol. 94: 1436-1443, 1990.

Kiymaz S., Ertek A.: Yield and quality of sugar beet (Beta vulgaris L.) at different water and nitrogen levels under the climatic conditions of Kirsehir, Turkey. - Agr. Water Manage. 158: 156-165, 2015.

Lang Y., Zhang G., Zhang Z. et al.: [Light response of photosynthesis and its simulation in leaves of Prunus sibirica under different soil water conditions.] - Acta Ecol. Sin. 31: 4499-4508, 2011. [In Chinese]

Li D., Tian M., Cai J. et al.: Effects of low nitrogen supply on relationships between photosynthesis and nitrogen status at different leaf position in wheat seedlings. - Plant Growth Regul. 70: 257-263, 2013.

Li Q., Luo Y.H., Dong H. et al.: Effects of low nitrogen stress on photosynthetic characteristics and chlorophyll fluorescence parameters of maize cultivars tolerant to low nitrogen stress at the seedling stage. - J. Plant Nutr. Fert. 21: 1132-1141, 2015. [In Chinese] 
Lin Y.C., Hu Y.G., Ren C.Z. et al.: Effects of nitrogen application on chlorophyll fluorescence parameters and leaf gas exchange in naked oat. - J. Integr. Agr. 12: 2164-2171, 2013.

Lin Z.H., Chen L.S., Chen R.B. et al.: $\mathrm{CO}_{2}$ assimilation, ribulose1,5-bisphosphate carboxylase/oxygenase, carbohydrates and photosynthetic electron transport probed by the JIP-test, of tea leaves in response to phosphorus supply. - BMC Plant Biol. 9: 43, 2009.

Lin Z.H., Zhong Q.S., Chen C.S. et al.: Carbon dioxide assimilation and photosynthetic electron transport of tea leaves under nitrogen deficiency. - Bot. Stud. 57: 37, 2016.

Liu X., Li Y.: Varietal difference in the correlation between leaf nitrogen content and photosynthesis in rice (Oryza sativa L.) plants is related to specific leaf weight. - J. Integr. Agr. 15: 2002-2011, 2016.

Long S.P., Marshall-Colon A., Zhu X.G.: Meeting the global food demand of the future by engineering crop photosynthesis and yield potential. - Cell 161: 56-66, 2015

Makino A.: Photosynthesis, grain yield, and nitrogen utilization in rice and wheat. - Plant Physiol. 155: 125-129, 2011.

Malnou C.S., Jaggard K.W., Sparkes D.L.: Nitrogen fertilizer and the efficiency of the sugar beet crop in late summer. - Eur. J. Agron. 28: 47-56, 2008.

Miranzadeh H., Emam Y., Pilesjö P., Seyyedi H.: Water use efficiency of four dryland wheat cultivars under different levels of nitrogen fertilization. - J. Agr. Sci. Tech. 13: 843-854, 2011.

Pal M., Rao L.S., Jain V. et al.: Effects of elevated $\mathrm{CO}_{2}$, and nitrogen on wheat growth and photosynthesis. - Biol. Plantarum 49: 467-470, 2005.

Qu W., Cui J.: [Effect of nitrogen application amount on nitrogen metabolism, yield and quality in sugar beet.] - China Sugar Beet 4: 16-21, 1994. [In Chinese]

Ruiz M., Aguiriano E., Carrillo J.M.: Effects of N fertilization on yield for low-input production in Spanish wheat landraces (Triticum turgidum L. and Triticum monococcum L.). - Plant Breeding 127: 20-23, 2008.

Shangguan Z., Shao M., Dyckmans J.: Effects of nitrogen nutrition and water deficit on net photosynthetic rate and chlorophyll fluorescence in winter wheat. - J. Plant Physiol. 156: 46-51, 2000.

Shao J.W.: Beet Physiology. Pp.179-182. Agricultural Press Publ., Beijing 1991.

Sun J.W., Yao F.Q., Wu J.B.: Effect of nitrogen levels on photosynthetic parameters, morphological and chemical characters of saplings and trees in a temperate forest. - J. Forestry Res. 29: 1481-1488, 2018.

Sun X.S., Lin Q., Zhao C.X. et al.: [Effects of nitrogen application rate on light-response curves of flag leaves in super-high yielding winter wheat at grain filling stage.] - Acta Ecol. Sin. 29: 1428-1437, 2009. [In Chinese]

Teng S., Qian Q., Zeng D. et al.: QTL analysis of leaf photosynthetic rate and related physiological traits in rice (Oryza sativa L.). - Euphytica 135: 1-7, 2004.

Thornley J.H.: Mathematical Models in Plant Physiology. Pp. 86-110. Academic Press, London 1976.

Tsialtas J.T., Maslaris N.: Sugar beet response to N fertilization as assessed by late season chlorophyll and leaf area index measurements in a semi-arid environment. - Int. J. Plant Prod. 2: 57-70, 2008

Wang S., Han X.R., Zhan X.M. et al.: [The comparative study on fitting light response curve model of photosynthesis of maize under different nitrogen fertilizer levels.] - J. Plant Nutr. Fert. 20: 1403-1412, 2014. [In Chinese]

Westoby M.: The worldwide leaf economics spectrum. Nature 428: 821-827, 2004.

Yang M.D., Ma S.C., Yang S.J. et al.: [Effects of postponing nitrogen application on photosynthetic characteristics and grain yield of winter wheat subjected to water stress after heading stage.] - Chin. J. Appl. Ecol. 26: 3315-3321, 2015. [In Chinese]

Ye Z P., Yu Q.: [Comparison of new and several classical models of photosynthesis in response to irradiance.] - J. Plant Ecol. 32: 1356-1361, 2008. [In Chinese]

Zhang Y., Wang J., Gong S. et al.: [Photosynthetic response of yield enhancement by nitrogen fertilization in winter wheat fields with drip irrigation.] - Trans. Chin. Soc. Agr. Eng. 31: 170-177, 2015. [In Chinese]

Zhang Y.Q., Wang J.D., Gong S.H. et al.: Nitrogen fertigation effect on photosynthesis, grain yield and water use efficiency of winter wheat. - Agr. Water Manage. 179: 277-287, $2017 \mathrm{a}$.

Zhang Z., Zheng E., Wang C. et al.: [Effect of different water and nitrogen levels on chlorophyll fluorescence parameters and photosynthetic characteristics of rice.] - Trans. Chin. Soc. Agr. Mach. 48: 176-183, 2017b. [In Chinese]

Zheng R., Kang S., Hu X. et al.: [Effects of water and nitrogen conditions on the diurnal variation of photosynthesis characteristic and yield of grapevine in arid oasis region.] Trans. Chin. Soc. Agr. Eng. 29: 133-141, 2013. [In Chinese]

(C) The authors. This is an open access article distributed under the terms of the Creative Commons BY-NC-ND Licence. 